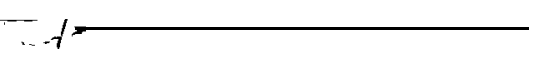

Proceedings of the New Zealand Grassland Association 51:151-156 (1990)

\title{
Performance of new pasture cultivars in a hill country finishing system
}

\author{
R.W. Webby, G.W. Sheath and C.J. Boom \\ Whatawhata Research Centre, MAFTech, \\ Private Bag, Hamilton
}

\begin{abstract}
On 6 of a set of 12 self-contained experimental farmlets, improved pasture cultivars 'Ellett' ryegrass, 'Grasslands Wana' cocksfoot, 'Grasslands Tahora' white clover, Whatawhata Early Flowering' white clover, 'Mount Barker' sub clover, 'Tallarook' sub clover, 'Grasslands Matua' prairie grass, 'Grasslands Pitau' white clover and 'Grasslands Pawera' red clover were successfully established in 1986. Measurements began May 1987. Results presented to May 1989 include pasture production, animal production and financial returns. Matua prairie grass failed to persist beyond spring 1988 but clovers including Pawera and Pitau in these pastures increased summer production in 1989. In summer 1989 the improved steep pastures produced $8 \mathrm{~kg} \mathrm{DM} / \mathrm{ha} /$ day more feed than the resident pastures, with most of this increase owing to Wana cocksfoot. Lamb numbers and lamb weight gains were greater with improved pastures. Bulls were priority finishing animals and their weights were insensitive to pasture treatment. Current returns from this experiment show little to justify the investment made in introducing new cultivars into existing developed hill pastures.
\end{abstract}

Keywords pasture cultivars, hill country, finishing systems, pasture improvement

\section{INTRODUCTION}

The productive merits of many improved pasture cultivars are known (Barker 1985; Goold 1985; Cosgrove 1985; Macfarlane 1984; Chapman 1986), but information is sparse on their role within a sheep and beef hill property.

Traditional hill farming operations are geared to the production from resident pastures. Moves to maintain economic viability such as early lambing and livestock finishing exacerbate the shorffalls in these pastures. Of greatest concern are quantity deficiencies in late winter and quality problems in summer. These shortfalls may be overcome by introducing new cultivars into hill country.

When a farm has been developed to the point where subdivision and grazing management are not limiting production, soil fertility is being maintained and pastures are dominantly ryegrass-white clover, we might ask whether new plant cultivars increase farm production.

A set of 12 self-contained farmlets on the
Whatawhata Research Centre was used to evaluate the merits of introducing new pasture cultivars into a hill country finishing system.

\section{EXPERIMENTAL}

\section{Trial design}

The trial design was a $2 \times 2$ factorial with 3 replicates. Factors were improved vs resident pasture and early vs late lambing. The lambing treatments are described by Sheath et al. (1990). Measurements of plant and animal production began in May 1987, 8-12 months after oversowing and drilling.

\section{Farmlets structure}

Each farmlet has half of its productive capacity on steep contoured land (approx. 2/3 land area) and one half on easy contoured land (approx. 1/3 land area). Approximately $70 \%$ (of easy contoured land) was workable with a 4-wheel. drive tractor. All the steepland was sown in the improved cultivars and the Matua sown on the workable easy paddocks. The remaining easy land (about $11 \%$ of total land area of the farm) comprising 2 paddocks per farmlet was not sown. The farmlets each had on average 12 paddocks

6 easy, 6 steep, totalling 5.4-6 ha, subdivided into dominant strata and aspect.

\section{Stock policy}

Coopworth x Romney ewes (9.2/ha) and Friesian bulls were run with lambs, 6/ha in 1987188 and 5/ha in 1988189, that were retained at weaning. Lambs were disposed of in late January. Friesian bull calves were introduced in November ( 5 per farmlet), with 20-month bulls leaving the trial in late January. Animal management was as described by Sheath et al. (1990).

\section{Establishment technique}

Improved cultivars were introduced to 6 of the farmlets.

Steepland In May 1986 steepland paddocks were oversown using a technique described by Macfarlane (1986), using Spraygrow (a formulation of $150 \mathrm{~g} / \mathrm{l}$ paraquat and $25 \mathrm{~g} / \mathrm{l}$ diquat) at $2 \mathrm{l} / \mathrm{ha}$, oversowing and treading with stock.

In autumn 1986 the sowing rates $(\mathrm{kg} / \mathrm{ha})$ of total seeds were: 'Ellett' ryegrass 16; 'Grasslands Wana' cocksfoot 7.5; 'Grasslands Tahora' white clover 3.0; WEF white clover 3.5; 'Mt Barker' sub clover 4.4; 'Tallarook' sub clover 4.4.

The Ellett ryegrass had an endophyte level of $80 \%$ at time of sowing. 
Matua paddocks Preparation was as described by Macfarlane (1986) with Roundup (360 g/l glyphosate) herbicide at 3 1/ha being used to improve weed and clover control. The Matua was direct-drilled with an Aitchison Seedamatic Tine drill. The Pawera and Pitau seeds were broadcast over the drill rows before harrowing. The Matua seed was treated according to Clark's (1985) recommendations.

In spring 1986 cultivars and sowing rates $(\mathrm{kg} / \mathrm{ha})$ were: 'Grasslands Matua' prairie grass 40; 'Grasslands Pitau' white clover 3; 'Grasslands Pawera' red clover 5.

\section{RESULTS}

\section{Background resident pastures}

Resident pastures (Table 1) have evolved from sowings before 1970 and would reflect the background soil fertility and moisture history of the block. Annual pasture production on average has been $7000 \mathrm{~kg}$ $\mathrm{DM} / \mathrm{ha}$ on steepland and $11000 \mathrm{~kg} \mathrm{DM} / \mathrm{ha}$ on easy land.

\section{Establishment of new pastures}

Establishment of both Matua and the steep oversown pastures was highly successful (Table 2 and 2A). Pasture composition in the steep pastures is being monitored. Initial results indicate little change in the

Table 1 Background composition for resident pastures (hits per 100 points).

\begin{tabular}{|c|c|c|c|}
\hline & Good easy & Medium steep & steep \\
\hline Ryegrass & 68 & 42 & 37 \\
\hline Browntop & 31 & 36 & 31 \\
\hline Poa annua & 30 & 11 & 08 \\
\hline Other grasses & 18 & 29 & 40 \\
\hline White clover & 47 & 31 & 23 \\
\hline
\end{tabular}

Table 2 Establishment 7 weeks after sowing on steep land.

\begin{tabular}{lcccc}
\hline & \multicolumn{4}{c}{ Established } \\
& $\begin{array}{r}\text { Viable } \\
\text { seeds/m }\end{array}$ & 2 Southerly & $\begin{array}{c}\text { Northerly } \\
\text { moderate }\end{array}$ & $\begin{array}{c}\text { Northerly } \\
\text { steep }\end{array}$ \\
\hline Ryegrass (Ellett) & 650 & 53 & $\mathbf{6 9}$ & 64 \\
Cocksfoot (Wana) & 740 & 19 & $\mathbf{2 2}$ & 18 \\
White clovers & 900 & 43 & $\mathbf{5 1}$ & $\mathbf{5 0}$ \\
Sub clovers & 95 & Not sown & $\mathbf{5 2}$ & 59 \\
\hline
\end{tabular}

Table 2A Matua plants established 6 months after sowing.

\begin{tabular}{lc}
\hline & Plants $/ \mathrm{m}^{2}$ \\
Matua tillers & 569 \\
Matua seedlings & 159 \\
Pawera plants & 15.1 \\
\hline
\end{tabular}

amount of ryegrass and white clover between the new and resident pastures. However, Wana cocksfoot, not present in the resident pastures, contributes significantly to the composition of the improved pastures.

\section{Pasture growth}

Matua pastures In the winter and spring of 1987 Matua pastures produced less herbage than resident pastures. In the summer of $1987 / 88$, Matua pastures outproduced the resident (Table 3 ). This advantage came from both the Matua and the red clover component of the pasture. By the summer of 1988189, Matua growth was reduced to only $0.9 \mathrm{~kg}$ DM/day, but the combination of red and white clovers again made these pastures more productive than resident.

Improved steepland pastures The improved steepland pastures have consistently outproduced the resident; the greatest differences occurred in late spring and summer 1988/89 (Table 4). Wana cocksfoot produced $27 \%$ of the grass leaf in late spring 1988 and $31 \%$ in summer 1989. There was no difference in clover or ryegrass production between the improved steep and resident pasture. In the first year of pasture measurements (1-6-87 to $31-5-88$ ), resident steep pastures produced $8997 \mathrm{~kg} \mathrm{DM} / \mathrm{ha}$, and improved steep pastures $9728 \mathrm{~kg} \mathrm{DM} / \mathrm{ha}$. In the late spring and summer of 1989190 alone, improved steep pastures produced $1100 \mathrm{~kg} \mathrm{DM} / \mathrm{ha}$ more than the resident steep pastures.

\section{Animal performance}

Ewe performance All ewes were managed the same until randomised into treatments in May 1987. Little variation between lambs born per ewe lambing and lambs weaned per ewe mated could be expected (Table 5). The poorer survival of lambs to weaning (in 1987) on improved farms reflected the difficulty of managing Matua in a rationing scene before lambing. Lamb losses occurred through bearings and lambing difficulties owing to large lambs. In the second year, grazing management was adjusted to overcome this problem. In 1988 the full effects of pasture improvement were in place and higher lamb numbers match the $2 \mathrm{~kg}$ weight difference at mating (Table 6). Some of this advantage may have resulted from the lower lamb numbers weaned in 1987. However, at weaning 1988 improved farms were lighter by 0.9 $\mathrm{kg} /$ ewe but from an equal start in January had improved to be ahead by $1.1 \mathrm{~kg}$ by April 1989 .

Wool production was $4.12 \mathrm{~kg}$ greasy fleece weight per ewe in 1987 and 4.21 and 4.24 in 1988 for resident and improved farms respectively. At $\$ 3.95 / \mathrm{kg}$ greasy fleece weight; return from improved farmlets increased approximately \$10/ha in 1987 and \$1/ha in 1988 .

Lamb weights At weaning in 1987, lambs from improved farms were $1.4 \mathrm{~kg}$ heavier (Table 7), possibly a result of fewer lambs on the improved farms 
Table 3 Production from the improved easy (Matua, Pitau and Pawera) pastures and resident easy pastures.

\begin{tabular}{|c|c|c|c|c|c|c|c|c|}
\hline kg DM/ha/day & $\begin{array}{c}1987 \\
\text { winter }\end{array}$ & $\begin{array}{c}1987 \\
\text { spring }\end{array}$ & $\begin{array}{l}1987 / 88 \\
\text { summer }\end{array}$ & $\begin{array}{c}1988 \\
\text { autumn }\end{array}$ & $\begin{array}{c}1988 \\
\text { winter }\end{array}$ & $\begin{array}{c}1988 \\
\text { spring }\end{array}$ & $\begin{array}{c}\text { Late } \\
\text { spring }\end{array}$ & $\begin{array}{c}1989 \\
\text { summer }\end{array}$ \\
\hline \multicolumn{9}{|c|}{ Production of grass leaf: } \\
\hline $\begin{array}{l}\text { Resident } \\
\text { Improved } \\
\text { (Actual Matua) }\end{array}$ & $\begin{array}{c}17.4 \\
16.8 \\
(16.1)\end{array}$ & $\begin{array}{l}27.8 \\
13.8 \\
(7.3)\end{array}$ & $\begin{array}{c}10.9 \\
16.0 \\
(11.8)\end{array}$ & $\begin{array}{l}44.1 \\
42.5 \\
(38.7)\end{array}$ & $\begin{array}{r}17.7 \\
\mathbf{1 5 . 3} \\
(13.4)\end{array}$ & $\begin{array}{l}32.2 \\
27.5 \\
(9.3)\end{array}$ & $\begin{array}{l}29.8 \\
23.2 \\
(7.7)\end{array}$ & $\begin{array}{l}\mathbf{1 3 . 6} \\
14.5 \\
(0.9)\end{array}$ \\
\hline SED & 2.9 & 4.3 & 5.1 & 4.9 & 0.7 & 3.4 & 4.8 & 3.9 \\
\hline \multicolumn{9}{|c|}{ Production from clovers: } \\
\hline $\begin{array}{l}\text { Resident } \\
\text { Improved } \\
\text { (Red Clover) }\end{array}$ & $\begin{array}{r}2.6 \\
0\end{array}$ & $\begin{array}{c}18.1 \\
24.5 \\
(14.5)\end{array}$ & $\begin{array}{c}8.8 \\
17.2 \\
(10.8)\end{array}$ & $\begin{array}{c}9.1 \\
10.7 \\
\mathbf{( 5 . 2 )}\end{array}$ & $\begin{array}{r}2.7 \\
1.6 \\
(0.5)\end{array}$ & $\begin{array}{r}6.4 \\
6.8 \\
(3.4)\end{array}$ & $\begin{array}{l}13.3 \\
19.6 \\
(9.1)\end{array}$ & $\begin{array}{c}1.1 \\
16.9 \\
(6.8)\end{array}$ \\
\hline SED & 1.0 & 8.6 & 4.7 & 3.4 & 0.8 & 3.1 & 1.9 & 4.4 \\
\hline \multicolumn{9}{|c|}{ Production of grass \& clover: } \\
\hline $\begin{array}{l}\text { Resident } \\
\text { Improved }\end{array}$ & $\begin{array}{c}20.0 \\
16.8\end{array}$ & $\begin{array}{l}53.4 \\
49.7\end{array}$ & $\begin{array}{c}18.5 \\
33.0\end{array}$ & $\begin{array}{c}53.2 \\
53.2\end{array}$ & $\begin{array}{l}20.4 \\
16.9\end{array}$ & $\begin{array}{r}38.7 \\
34.3\end{array}$ & $\begin{array}{c}42.6 \\
43.3\end{array}$ & $\begin{array}{l}14.5 \\
31.5\end{array}$ \\
\hline SED & 3.6 & 7.1 & $\ddot{7.0}$ & 3.4 & $\ddot{1.1}$ & 5.2 & 5.7 & 7.9 \\
\hline
\end{tabular}

Note: SED standard error of the difference on main effect.

Table 4 Production from improved and resident steep pastures.

\begin{tabular}{|c|c|c|c|c|c|c|c|c|}
\hline kg DM/ha/day & $\begin{array}{c}1987 \\
\text { winter }\end{array}$ & $\begin{array}{c}1987 \\
\text { spring }\end{array}$ & $\begin{array}{c}1988 \\
\text { summer }\end{array}$ & $\begin{array}{c}1988 \\
\text { autumn }\end{array}$ & $\begin{array}{c}1988 \\
\text { winter }\end{array}$ & $\begin{array}{c}1988 \\
\text { spring }\end{array}$ & $\begin{array}{l}\text { Late } \\
\text { spring }\end{array}$ & $\begin{array}{c}1989 \\
\text { summer }\end{array}$ \\
\hline \multicolumn{9}{|c|}{ Production of grass leaf $\mathrm{kg} \mathrm{DM} / \mathrm{ha} / \mathrm{day}$ : } \\
\hline Resident & 13.5 & - & 9.4 & 27.6 & 16.1 & - & 20.3 & 12.5 \\
\hline Improved & 16.7 & - & 15.4 & 31.3 & 17.4 & - & 28.6 & 21.0 \\
\hline (Wana) & -1 & - & - & - & - & - & (7.8) & $(6.6)$ \\
\hline SED & 1.1 & & 3.3 & 1.7 & 1.4 & - & 3.9 & 2.9 \\
\hline \multicolumn{9}{|c|}{ Production from grass and legume: } \\
\hline Resident & 15.3 & 34.6 & 15.6 & 33.2 & 17.4 & 24.8 & 29.0 & 15.6 \\
\hline Improved & 18.3 & 35.2 & 18.5 & 34.7 & 18.6 & 24.3 & 37.3 & 23.4 \\
\hline SED & 1.1 & 3.6 & 3.2 & 2.0 & 1.3 & 1.4 & 4.7 & 5.2 \\
\hline
\end{tabular}

'Fractions not measured during these periods.

(Table 5). However, at weaning in 1988, weights were the same despite a heavier lamb drop on improved farms.

During Nov-Jan 1987/88 improved farmlet lambs grew at $12 \mathrm{~g} /$ day faster and during Nov-Jan 1988/89, $18 \mathrm{~g} /$ day faster than lambs on resident farmlets.

Lamb values To give a realistic meaning of lamb weights in dollar terms, all lambs were valued (Table 8).

The 1988 prices were extremely low compared with those in 1987, but they recovered and strengthened through January to March 1989, whereas at the same time in 1988 lamb prices had weakened. In 1987/88 lamb losses in improved farmlets slightly lowered revenue, while in 1988/89 more weaned lambs and better lamb growth rates gave a $\$ 14 /$ ha advantage to improved farmlets.

Bull performance In the first year $(1987 / 88)$ bulls from improved farms were $8 \mathrm{~kg}$ heavier, and in the second year $(1988 / 89) 9 \mathrm{~kg}$ heavier at slaughter. The $\$$ returns per bull were influenced by the number of animals in higher paying weight grades, and showed a \$22 advantage in 1988 to improved and a \$9 advantage in 1989 to resident pastures.

Economic evaluation Currently it would cost $\$ 5$ 10/ha to establish the Matua clover mix and $\$ 2^{4} i$, ha to establish the steepland pasture on clean country. On 
the experimental farms $\$ 290 /$ ha was spent for an additional return of $\$ 26$ and \$6/ha in 1987188 and 1988189 respectively.

Table 5 Lambs born and lambs weaned per ewe.

\begin{tabular}{lccc}
\hline & & $\mathbf{1 9 8 7}$ & 1988 \\
\hline Resident & (Lambs born) & 1.54 & 1.49 \\
Improved & (Ewes lambing) & 1.47 & 1.59 \\
SED & & 0.03 & 0.05 \\
Resident & (Lambs weaned) & 1.22 & 1.07 \\
Improved & (Ewes mated) & 1.07 & 1.20 \\
SED & & 0.03 & 0.04 \\
\hline
\end{tabular}

Table 6 Ewe liveweights $(\mathrm{kg})$

\begin{tabular}{|c|c|c|c|c|c|c|}
\hline & $\begin{array}{l}\text { Mid } \\
\text { Jan }\end{array}$ & 1 Mar & Apr & $\begin{array}{l}\text { Mid } \\
\text { May }\end{array}$ & $\begin{array}{l}\text { Mid } \\
\text { Nov }\end{array}$ & $\begin{array}{l}\text { Mid } \\
\text { Jan }\end{array}$ \\
\hline \multicolumn{7}{|l|}{$1987 / 88$} \\
\hline Resident & - & & - & 57.6 & 51.8 & 56.3 \\
\hline Improved & - & - & - & 57.6 & $\begin{array}{r}54.7 \\
\star \star\end{array}$ & $\begin{array}{r}58.7 \\
* \star\end{array}$ \\
\hline SED & & & & & $0.4^{*}$ & 0.4 \\
\hline \multicolumn{7}{|l|}{$1988 / 89$} \\
\hline Resident & 54.2 & 50.8 & 54.7 & 57.0 & 48.9 & 52.2 \\
\hline Improved & 55.7 & $\begin{array}{c}52.5 \\
* *\end{array}$ & • $\quad \begin{array}{r}56.7 \\
\square\end{array}$ & 59.2 & 48.0 & 51.7 \\
\hline SED & & 0.5 & 0.5 & & & \\
\hline \multicolumn{7}{|l|}{1989} \\
\hline Resident & 52.6 & 53.3 & 53.6 & 51.6 & - & \\
\hline Improved & 52.6 & 53.4 & 52.1 & - & & \\
\hline SED & & & 0.5 & & & \\
\hline
\end{tabular}

Note: Mid Nov weight is at lamb weaning.

Mid Jan weight at start is after CFA ewes are replaced by 2 -tooth ewes.

Table 7 Lamb liveweights $(\mathrm{kg})$.

\begin{tabular}{lcccc}
\hline & Wt at weaning & \multicolumn{3}{c}{ Retained lambs } \\
\hline & & Nov & Jan & g/day \\
1987/88 & & & & \\
Resident & 21.2 & 23.5 & 32.8 & 163 \\
Improved & 22.6 & 24.1 & 34.1 & 175 \\
& & & & \\
SED & 0.3 & & 0.4 & \\
1988/89 & & & & \\
Resident & 19.9 & 21.9 & 31.1 & 148 \\
Improved & 20.0 & 22.1 & 32.4 & 166 \\
& & & $\cdot \cdot$ & \\
SED & 0.4 & & 0.4 & \\
\hline
\end{tabular}

Table 8 Lamb values: potential at weaning and actual sale values.

\begin{tabular}{|c|c|c|}
\hline & $\begin{array}{l}1981 \\
\$ / \text { ha }\end{array}$ & $\begin{array}{l}1988 \\
\text { \$/ha }\end{array}$ \\
\hline \multicolumn{3}{|c|}{ Potential market value at weaning (all lambs) } \\
\hline Resident & 166 & 63 \\
\hline Improved & 156 & 71 \\
\hline SED & 5 & 4 \\
\hline \multicolumn{3}{|c|}{ Actual market value at dispoal (all lambs) } \\
\hline & 1987188 & $1988 / 89$ \\
\hline & $\$ /$ ha & $\$ /$ ha \\
\hline Resident & 184 & 126 \\
\hline Improved & 179 & 140 \\
\hline SED & 5 & 6 \\
\hline
\end{tabular}

\section{DISCUSSION}

Introducing new cultivars into existing hill country pastures gave no dollar advantage. However, the manner in which the trial was managed, the failure of Matua and the performance of the existing resident pastures have all affected the results.

The trial was managed using a whole-farm approach, adopting a profitable breeding/finishing system which combined breeding ewes with lamb and bull finishing. While lambs and bulls are particularly responsive to feeding, they were managed as priority animals and had least opportunity to reflect feed availability. Ewes were managed as the lowest priority animal and their performance shows up differences in feed supply. When all the interactions associated with the ewe are considered along with the inability of the new pastures to provide extra feed in early spring, the ewe responses were insufficient to justify the input cost. This poses the question: will high producing plant cultivars increase farm profitability? Given a system as run in this experiment, the answer at this stage would seem to be no.

The Matua pastures failed on three counts. Firstly, they outproduced the resident ryegrass pastures only in summer and much of that advantage came from the clover content; they did not produce the expected extra feed in winter or early spring.

Secondly, it did not persist. This poor persistence was associated with a weakening of the Matua plants during August-October, particularly during the very wet 1988 spring. Low soil nitrogen may have been the cause. Single-tillered plants were common in October and, once reproductive, they had little chance of surviving grazing and/or competition from invading 
ryegrass. Reseeding occurred during each summer but seedlings were unable to survive the competition and treading associated with a winter rotation. Insect damage (Argentine stem weevil and Hessian fly) in late spring-summer of 1988/89 was observed and may further have weakened the Matua. Similar damage has been reported by Thorn et al. (1989). Consequently, summer production of Matua in 1988/89 was only $8 \%$ of that in the previous year. The demise of the Matua allowed space for the clovers (Pawera and Pitau), maintaining production from these paddocks in summer 1989, but this high clover content did little for winter and early spring production.

Finally, Matua did not fit readily into a long winter rotation and was difficult to manage and ration feed to ewes at the same time. A lack of rationing power resulted in lamb losses due to overfeeding of ewes close to lambing. This problem was overcome by predominant bull feeding on Matua at that time in the second year.

Replacing resident genotypes of ryegrass and white clover by new cultivars on steepland did not increase the content or production contribution of these species. Other factors such as nitrogen and soil moisture status could be more limiting than the cultivar's genetic potential to produce. The greatest production benefit occurred when Wana cocksfoot was introduced into low-producing sites such as inter-track zones, areas on which ryegrass and white clover did not readily establish. The contribution from Wana is increasing and this plant's potential to produce summer feed may not yet have been fully reached. This emphasises the need for systems evaluation to continue for a number of years.

Given the type of pasture improvement and the animal production system used in this experiment, there seems little financial justification for the introduction of new cultivars into existing hill country pasture. If the extra production gained from the steepland was evaluated alone, the result would have been different. As an example; the potential of the additional production in late spring and summer 1988/89 from the improved steep pasture, of on average $8 \mathrm{~kg} \mathrm{DM} / \mathrm{ha} /$ day if fed to bulls, may have produced an extra $50 \mathrm{~kg} / \mathrm{ha}$ of bull beef or $\$ 125 / \mathrm{ha}$, or if fed to lambs $38 \mathrm{~kg} / \mathrm{ha}$ or $\$ 44 / \mathrm{ha}$ (on summer 1989 prices). However, any advantages gained on oversown steepland were cancelled out by the failure of Matua on easy land. We have now moved to replace the Matua with Marsden ryegrass (a high endophyte Ariki) and will continue to monitor the combined results from this sowing and the improved steepland.

\section{CONCLUSIONS}

Introducing new cultivars increased pasture and animal production.

Establishment was successful but the persistence of Matua prairie grass was poor.

Wana cocksfoot provided additional feed in summer and autumn and this contribution appears to be increasing with time.

Ewe performance and lamb growth rates were more sensitive measures of pasture production in this trial than bull or ewe wool weights.

Acknowledgements The services of $M$. Herlihy for data handling and P. Evans for stock movement are gratefully acknowledged.

\section{REFERENCES}

Barker, D.J.; Lancashire, J.A.; Meurk, C. 1985. 'Grasslands Wana cocksfoot - an improved grass suitable for hil country. Proceedings of the NZ Grassland Association 46: $167-172$.

Chapman, D.F.; Sheath, G.W.; Sheath, G.W.; Macfarlane, M.J.; Rumball, P.J.; Cooper, B.M.; Crouchley, G.; Hoglund, J.H.; Widdup, K.H. 1986. Performance of subterranean white clover variation in dry hill country. Proceedings of the NZ Grassland Association 47: 53-62.

Clark, P. 1985. Matua Prairie grass establishment. Proceeding of the NZ Grassland Association 46: 147-149.

Cosgrove, G.P.; Brougham, R.W. 1985. Grazing management influences of seasonlity and performance of ryegrass and red clover in a mixture. Proceedings of the NZ Grassland Association 46: 71-76.

Falloon, R.E. 1985. Prairie grass establishment affected by seed treatment and sowing date. Proceedings of the NZ Grassland Association 46: 141-146.

Fraser, T.J. 1985. Role of Matua Prairie grass in all grass system for prime lamb production. Proceedings of the NZ Grassland Association 46: 157-161.

Goold, G.J.; Weeda, W.C. 1985. The value of regrassing with improved Dasture cultivars in Waikato. Proceedings of the NZ Grassland Association 46: 179-183.

Macfarlane, M.J.; Sheath, G.W. 1984. Clover - what types for dry hill country? Proceedings of NZ Grassland Association 45: 140-150.

Macfarlane, M.J.; Bonish, P.M. 1986. Oversowing white clover into cleared unimproved north island hill country - The role of management, fertiliser, inoculation, pelleting and resident rhizobia. Proceedings of the NZ Grassland Association 47: 43-51.

Sheath, G.W.; Webby, R.W.; Pengelly, W.J.; Boom, C.J. 1990. Finishing lambs in hill country. Proceedings of the $N Z$ Grassland Association 51: (in press)

Thorn, E.R.; Prestidge, R.A.; Van der Zijpp, S. 1989. Effects of pests and diseases on prairie grass production under dairying in the Waikato region of NZ. Proceedings of the 5th Australian Conference on Grasslands Invertebrate Ecology: 314-322. 